\title{
EVALUASI KINERJA KEUANGAN PERUSAHAAN MAKANAN BERBASIS ANALISIS RASIO KEUANGAN: SEBUAH STUDI KASUS
}

\author{
Alexander Joseph Ibnu Wibowo \\ School of Business and Economics, Universitas Prasetiya Mulya \\ Jl. BSD Raya Barat I, BSD City, Serpong, Tangerang 15339, Indonesia \\ Email: ibnu.wibowo@pmbs.ac.id
}

\begin{abstract}
Abstrak
Penelitian ini bertujuan untuk menganalisis tren kinerja keuangan sebuah perusahaan makanan dan menguji validitas instrumen rasio keuangan yang selama ini digunakan oleh kalangan praktisi dan akademisi keuangan. Untuk itu, kami merancang sebuah studi penjajakan melalui sebuah studi kasus tunggal di sebuah perusahaan makanan yang terdaftar di Bursa Efek Indonesia (BEI). Kami menganalisis data keuangan perusahaan menggunakan berbagai analisis rasio yang umum digunakan dalam disiplin keuangan, seperti rasio operasional, rasio keuangan, dan kinerja saham. Analisis diperdalam dengan memaparkan hasil analisis faktor untuk menguji validitas instrumen rasio keuangan. Kami menemukan bahwa kinerja keuangan perusahaan cenderung berfluktuasi dari waktu ke waktu. Jika dilihat dari sisi penjualan, maka kinerja perusahaan menunjukkan peningkatan sejak tahun 2010. Jika kita amati dari marjin laba, maka kinerja keuangan perusahaan cenderung mengalami penurunan. Tren rasio operasional juga memperlihatkan penurunan sejak tahun 2013 hingga 2015. Selanjutnya, hasil analisis faktor menunjukkan bahwa rasio laba bersih terhadap aset keseluruhan merupakan indikator terkuat untuk mengukur rasio keuangan perusahaan. Berbeda dengan studi-studi sebelumnya, penelitian ini menemukan bahwa rasio laba usaha terhadap ekuitas tidak terbukti valid sebagai alat ukur rasio keuangan. Secara ringkas, penelitian ini berhasil memberikan kontribusi signifikan dan kebaruan bagi kepentingan praktis maupun teoritis (pengetahuan) melalui validasi instrumen rasio keuangan yang banyak digunakan selama ini.
\end{abstract}

Kata kunci: Rasio Keuangan, Kinerja, Makanan, Studi Kasus, Indonesia

\begin{abstract}
This study aims to analyze trends in financial performance of a food company and test the validity of financial ratio instruments that have been used by financial practitioners and academics. For this reason, we designed an exploratory study through a single case study at a food company listed on the Indonesia Stock Exchange (IDX). We analyze the company's financial data using a variety of ratio analysis commonly used in financial disciplines, such as operational ratios, financial ratios, and stock performance. The analysis was deepened by describing the results of factor analysis to test the validity of financial ratio instruments. We find that the company's financial performance tends to fluctuate over time. When viewed from the sales side, the company's performance showed an increase since 2010. If we observe the profit margin, the company's financial performance tends to decrease. Operational ratio trends also show a decline from 2013 to 2015. Furthermore, the results of factor analysis indicate that the ratio of net income to overall assets is the strongest indicator to measure the company's financial ratios. In contrast to previous studies, this study found that the ratio of operating income to equity was not proven valid as a measure of financial ratios. In summary, this study succeeded in providing significant contributions and novelty for practical and theoretical interests through the validation of financial ratios that are widely used so far.
\end{abstract}

Keywords: Financial Ratio, Performance, Food, Case Study, Indonesia

\section{PENDAHULUAN}

Analisis rasio keuangan merupakan topik penting dan ditemukan dalam seluruh buku teks keuangan korporasi. Rasio keuangan telah digunakan sebagai cara yang efisien biaya dan mudah untuk menjaga jalur kondisi keuangan (Yeh, 1996). Rasio keuangan dianggap berguna untuk memprediksi kesulitan keuangan perusahaan (Horrigan, 1965). Analisis ini luas digunakan untuk merangkum informasi dalam laporan keuangan perusahaan untuk menganalisis kondisi dan kinerja keuangan (Hsu, 2010). Di lain pihak, 
kinerja perusahaan telah menjadi isu penting di negara berkembang. Evaluasi kinerja perusahaan dan pengawasan atas kondisi keuangan penting bagi pemilik, investor potensial, manajer, dan juga regulator (AlTamimi \& Lootah, 2007).

Rasio keuangan merupakan alat analisis untuk studi tentang sejumlah konsep seperti aktivitas, profitabilitas atau produktivitas sebuah perusahaan (Gallizo, Gargallo \& Salvador, 2008). Analisis rasio keuangan bisa menjadi perspektif alternatif untuk menelaah cara menghindari kebangkrutan korporasi (Sueyoshi, 2005). Menurut Horrigan (1965), diduga perusahaan yang ada di dalam sebuah industri cenderung menjaga posisi rasio keuangan yang relatif stabil dalam periode waktu yang sangat panjang, meskipun pola-pola bervariasi di antara jenis-jenis rasio dan industri. Ada beberapa sifat statistik penting dari rasio keuangan, seperti berdistribusi normal, berkorelasi kuat satu sama lain, dan berkorelasi kuat dari waktu ke waktu. Oleh karena itu, rasio keuangan menerima analisis statistikal.

Analisis rasio keuangan dianggap sebagai pendekatan standard untuk mengevaluasi kinerja keuangan. Berbagai peneliti telah mengkaji penggunaan analisis rasio keuangan sebagai sebuah teknik untuk menilai profitabilitas, utilisasi aset, struktur utang, dan likuiditas dalam perusahaan. Namun, analisis rasio juga dinilai memiliki kelemahan utama, yaitu subjektivitasnya (Ozcan \& McCue, 1996). Menurut Bernstein, seperti disampaikan oleh Ozcan et al. (1996), ada beberapa kriteria yang dapat digunakan untuk mengukur kinerja keuangan organisasi secara keseluruhan. Laba dan penjualan merupakan dua ukuran yang paling luas digunakan.

Return on assets ratio (ROA) - yaitu rasio laba bersih terhadap total aset - dianggap sebagai ukuran kinerja keuangan keseluruhan yang sangat baik. Namun, ukuran ini sendiri tidak menunjukkan bagaimana sebuah organisasi meraih profitabilitasnya. Ada dua komponen rasio ROA, yaitu total margin (rasio laba bersih terhadap total pendapatan) dan rasio total asset turnover (rasio total pendapatan terhadap total aset). Dengan menganalisis komponen ini, seseorang bisa menentukan apakah memperoleh marjin laba bersih tertinggi menghasilkan pendapatan tertinggi per aset, dan selanjutnya mendorong kinerja keuangan (Ozcan et al., 1996).

Studi Aripin, Tower dan Taylor (2011) memperlihatkan bahwa pengungkapan rasio keuangan oleh perusahaan sangat rendah (5,3 persen). Ditemukan juga bahwa pengungkapan lebih ekstensif terlihat dalam subkategori ukuran pasar saham, profitabilitas, dan struktur modal. Selain itu, informasi rasio aliran kas dan likuiditas disebutkan jauh lebih rendah. Perusahaan besar dan perusahaan dengan kepemilikan saham yang tersebar cenderung memberikan informasi rasio keuangan yang lebih ekstensif. Demikian pula, perusahaan yang beroleh laba cenderung mempertunjukkan pengungkapan rasio keuangan yang lebih ekstensif. Sebaliknya, perusahaan sumber daya alam (pertambangan) menyajikan rasio keuangan lebih rendah dibanding perusahaan sektor keuangan dan jasa.

Menurut Aripin et al. (2011), perusahaan pertambangan paling sedikit menyampaikan rasio keuangan karena mereka merasa tidak perlu mengungkapkan informasi ini. Hal ini terjadi kemungkinan karena mereka berkonsentrasi pada isu-isu nonfinansial lain, seperti kuantifikasi eksplorasi dan produksi cadangan, dan dampak lingkungan. Sebaliknya, perusahaan keuangan menyampaikan rasio keuangan terbesar dalam laporan tahunan mereka. Hal ini kemungkinan didorong oleh kenyataan bahwa mereka berada dalam industri yang sangat teregulasi, sehingga lebih banyak informasi yang mesti disampaikan kepada pengguna.

Demikian pula, berdasarkan teori keagenan (agency theory), diyakini bahwa tata kelola korporasi, inisiatif manajemen modal, konsentrasi kepemilikan, dan ukuran perusahaan akan mempengaruhi pengungkapan rasio keuangan secara sukarela. Perusahaan lebih suka menyampaikan lebih banyak informasi yang berdampak langsung pada nilai perusahaannya (Aripin et al., 2011). Kemampuan untuk menampilkan analisis keuangan atas kinerja sebuah perusahaan sering krusial, khususnya dalam kasus di mana informasi kualitatif alternatif terkait pengelolaan perusahaan, organisasi, fasilitas teknis, posisi di pasar, dan lainnya sulit diperoleh (Voulgaris, Doumpos \& Zopounidis, 2000). Faktor yang dianggap paling sering ditemukan mampu meningkatkan penyebaran rasio keuangan, yaitu: klasifikasi industri, ukuran perusahaan, kondisi siklikal, kondisi musim, lokasi geografis, dan metode akuntansi (Horrigan, 1965).

Secara spesifik, tujuan penelitian ini yaitu menganalisis tren kinerja keuangan PT " $X$ ", salah satu perusahaan makanan di Indonesia yang telah terdaftar di BEI. Kami menganalisis data keuangan perusahaan menggunakan berbagai analisis rasio keuangan yang umum digunakan dalam disiplin keuangan, seperti rasio operasional, rasio keuangan, dan kinerja saham. Analisis diperdalam dengan memaparkan hasil analisis faktor untuk menguji validitas instrumen dari rasio keuangan. Temuan studi ini diharapkan bisa menghasilkan temuan berarti mengenai kondisi keuangan perusahaan, sehingga perusahaan bisa melakukan pembenahan secara efektif.

Akhirnya, penelitian ini mengajukan dua pertanyaan penelitian atau rumusan masalah yang belum dijawab oleh studi-studi sebelumnya, yaitu: (i) belum ada studi sebelumnya yang mengevaluasi tren kinerja keuangan perusahaan makanan di Indonesia yang terdaftar di Bursa Efek Indonesia (BEI) secara komprehensif, yang berbasis pada rasio operasional, rasio keuangan, dan kinerja saham secara simultan; dan (ii) belum ada studi sebelumnya yang melakukan pengujian validitas dan reliabilitas terhadap setiap alat ukur dari rasio keuangan yang banyak dipahami dan digunakan selama ini. Melalui penelitian penjajakan (awal) ini, kami ingin memberikan kontribusi signifikan bagi kepentingan praktis dan teoritis (pengetahuan) melalui temuan kami untuk menjawab kedua pertanyaan di atas. Selanjutnya, secara sistematis organisasi penulisan artikel ini bisa dibagi menjadi enam bagian, yaitu pendahuluan, tinjauan pustaka, metode penelitian, analisis dan pembahasan, simpulan, serta diakhiri keterbatasan dan saran.

\section{TINJAUAN PUSTAKA}

Rasio keuangan merupakan ukuran yang biasa digunakan selama analisis atas aspek keuangan dari kinerja perusahaan. Meskipun rasio keuangan memperoleh banyak kritikan di dalam literatur akuntansi, manfaat akuntansi keuangan bersandar pada kegunaan rasio ini. Rasio keuangan memberikan representasi hasil atas keputusan internal dan kondisi eksternal secara 
kuantitatif yang penuh makna dan tidak bias. Rasio keuangan melayani sebagai perangkat untuk mendeteksi ketidakberesan dalam perilaku manajerial dan aset (harta) perusahaan. Dewasa ini sejumlah riset telah mengarah pada analisis atas kekuatan prediktif rasio keuangan sebagai ukuran kinerja dan kelangsungan hidup korporasi (Voulgaris et al., 2000).

Orientasi pengembangan, manajemen pemilik, kompleksitas teknologi, tingkat keyakinan terhadap informasi keuangan eksternal, dan suasana pelaporan keuangan signifikan mempengaruhi praktik pelaporan keuangan dalam studi terhadap usaha kecil dan menengah. Pertumbuhan usaha kecil dan menengah merupakan pendorong utama terhadap praktik pelaporan keuangan yang lebih baik (McMahon, 1999). Analisis rasio keuangan diajukan untuk mengkaji kinerja keuangan atas industri. Analisis atas leverage (debt) dan profitability (returns on equity) merupakan faktor finansial penting untuk menghindari kebangkrutan korporasi (Sueyoshi, 2005).

Menurut Ahrendsen \& Katchova (2012), rasio keuangan mewakili lima karakteristik finansial, yaitu: likuiditas, solvensi, profitabilitas, kapasitas pembayaran kembali, dan efisiensi finansial. Likuiditas merupakan kemampuan bisnis untuk memenuhi tanggung jawab finansial. Solvensi adalah kemampuan untuk membayar seluruh utang jika perusahaan dijual dan seluruh aset digunakan untuk melunasi utang. Profitabilitas merupakan perbedaan di antara nilai barang yang diproduksi dan biaya atas sumber daya yang digunakan dalam produksi. Kapasitas pembayaran kembali adalah kemampuan peminjam untuk membayar kembali utang dengan tepat waktu. Efisiensi finansial memperlihatkan bagaimana bisnis menggunakan aset secara efektif untuk menghasilkan pendapatan. Kelima kategori rasio keuangan di atas menjelaskan kinerja keuangan dan kelangsungan hidup bisnis. Beberapa rasio keuangan yang disarankan adalah: current ratio, debt-to-asset ratio, rate of return on assets, rate of return on equity, operating profit margin, term debt coverage ratio, assets turnover ratio, dan operating expense ratio (Ahrendsen \& Katchova, 2012).

Rasio keuangan didefinisikan sebagai hubungan matematis di antara dua kuantitas (Subramanyam dan Wild, 2009. Analisis rasio finansial dinilai penting karena beberapa alasan, seperti menyediakan insights atas kondisi keuangan perusahaan (Subramanyam \& Wild, 2009); sebuah alat sinyal (Mitchell, 2006); mengakses dan membandingkan kinerja perusahaan (Watson, Shrives \& Marston, 2002); dan komponen utama dalam studi prediktif (Neophytou dan Molinero, 2004).

Pengungkapan rasio keuangan dalam laporan tahunan didorong oleh beberapa motif: (i) pengungkapan dapat meningkatkan pemahaman pemangku kepentingan dengan menyediakan alat sederhana dan cepat yang menyoroti kinerja perusahaan. Penilaian kinerja perusahaan dapat meningkat jika data rasio disajikan menggunakan grafik atau tabel (Courtis, 1996) yang menggambarkan perubahan dari waktu ke waktu; (ii) mengkomunikasikan informasi rasio keuangan dapat memberikan pengguna laporan keuangan dengan informasi baru yang tidak disajikan secara lengkap dalam berbagai media tunggal (Watson et al., 2002). Informasi ini akan lebih bermakna bagi non-sophisticated users dalam mengevaluasi dan membuat keputusan investasi (Aripin et al., 2011).
Beberapa rasio tidak mungkin dihitung sendiri oleh pembaca karena ketiadaan informasi (Gibson, 1982). Oleh karena itu, penyediaan rasio dalam laporan tahunan dapat menyampaikan insights atas posisi kesehatan keuangan perusahaan kepada pembaca. Pengungkapan rasio keuangan akan secara efisien mengurangi waktu dan biaya untuk memperoleh dan memproses informasi (Watson et al., 2002). Graham, Harvey \& Rajgopal (2005) menyebutkan bahwa alasan perusahaan menyampaikan informasi yaitu menurunkan biaya modal dan menyampaikan informasi penting kepada investor yang tidak dimasukkan dalam laporan keuangan yang bersifat wajib (Aripin et al., 2011).

Pengungkapan informasi secara sukarela kepada pengguna mampu menurunkan masalah asimetri informasi. Asimetri informasi ini bisa meningkat akibat konflik hubungan keagenan (Healy \& Palepu, 2001). Tata kelola korporasi, inisiatif pengelolaan modal, konsentrasi kepemilikan, dan ukuran perusahaan akan berdampak pada pengungkapan rasio keuangan (Aripin et al., 2011).

Indikator finansial ditunjukkan dengan rasio keuangan. Rasio merupakan alat pengelolaan strategis yang memberikan pemangku kepentingan utama cara sistematis dan ringkas untuk mengorganisasikan data dalam laporan keuangan (seperti neraca, laporan keuangan, dan laporan aliran kas) ke dalam informasi yang bermakna. Rasio keuangan mengacu pada hubungan numerikal atau kuantitatif di antara dua variabel. Hubungan ini dapat diperlihatkan dalam beragam istilah, seperti persentase atau pecahan (Suarez, Lesneski \& Denison, 2011).

Kegunaan melakukan analisis rasio yaitu membuat informasi terkait dapat diperbandingkan karena formatnya terstandardisasi. Penggunaan angka tunggal mempunyai makna sedikit tanpa perbandingan relevan atau konteks. Oleh karena itu, nilai rasio perlu dibandingkan dengan rasio historis untuk mengidentifikasi tren selama periode waktu atau membuat perbandingan dengan standard industri untuk menilai apakah tujuan dan standard telah tercapai. Informasi ini lalu digunakan untuk menganalisis, merencanakan, dan membuat keputusan untuk membenahi kinerja organisasi dan untuk menentukan kondisi keuangan historis dan saat ini. Analisis rasio keuangan juga mengajak organisasi untuk membuat proyeksi tentang operasi bisnis, yang menyediakan insight berharga bagi masa depan organisasi (Suarez et al., 2011).

Analisis rasio keuangan mempertimbangkan empat aspek organisasi, yakni: likuiditas, profitabilitas, leverage, dan operasi. Likuiditas berkaitan dengan kecukupan kas perusahaan atau aset jangka pendek untuk memenuhi utang yang akan dibayar dalam setahun. Profitabilitas mengukur apakah operasi sehari-hari menghasilkan pendapatan memadai untuk menutup biaya dan investasi ulang dalam misi organisasi. Leverage ratio terkait dengan sumber pendanaan atas aset perusahaan, dengan fokus khusus pada jumlah utang jangka panjang. Rasio operasi digunakan untuk menilai efisiensi dan efektivitas. Rasio keuangan membantu pengambil keputusan mengidentifikasi kekuatan dan kelemahan keuangan dan mengambil tindakan tepat untuk membantu organisasi mencapai misinya. Misalnya, penurunan tren dalam current ratio bisa menjadi sinyal bahwa sumberdaya jangka pendek kurang mencukupi untuk menutupi utang tahun depan (Suarez et al., 2011). 
Analisis rasio keuangan memiliki keterbatasan. Meskipun analisis rasio dapat mengungkapkan berbagai hal tentang operasi organisasi serta membantu membenahi peramalan dan pengambilan keputusan, alat ini juga memiliki keterbatasan. Misalnya, kesimpulan yang diambil dari rasio seharusnya dikombinasikan dengan pengetahuan lain tentang manajemen organisasi dan aspek ekonomi. Jadi, penting untuk mempertimbangkan konteks yang tepat untuk analisis rasio. Nilai rasio keuangan bergantung pada akurasi dan validitas dari data yang digunakan (Suarez et al., 2011).

\section{METODE PENELITIAN}

Penelitian ini menerapkan metode kuantitatif untuk memperoleh temuan dan kesimpulan secara keseluruhan. Penelitian ini dirancang sebagai sebuah studi penjajakan (exploratory study) dan studi kasus tunggal (single case study) terhadap sebuah perusahaan makanan yang telah terdaftar di Bursa Efek Indonesia (BEI), yaitu PT "X". Studi ini menggunakan rasio keuangan dalam menilai efisiensi PT " $X$ ". Data diperoleh dari laporan tahunan dan laporan keuangan dari tahun 2004 hingga 2015. Secara spesifik, data diunduh dari website resmi perusahaan. Kami juga menganalisis tren beberapa indikator dalam laporan keuangan, seperti: penjualan bersih, harga pokok penjualan, laba kotor, biaya operasi, dan pendapatan operasi. Selain itu, kami juga menganalisis tren marjin laba kotor, marjin pendapatan operasi, dan marjin laba bersih.

Selanjutnya, kami menggunakan analisis rasio keuangan dan kinerja saham untuk mengukur kinerja keuangan perusahaan. Analisis rasio keuangan ini mencakup rasio operasional dan rasio keuangan. Secara rinci, rasio operasional meliputi rasio laba usaha terhadap ekuitas (operating income to equity), rasio laba bersih terhadap ekuitas (net profit to equity, rasio laba usaha terhadap jumlah aset (operating income to total assets), dan rasio laba bersih terhadap jumlah aset (net profit to total assets). Di lain pihak, rasio keuangan meliputi rasio aset lancar terhadap liabilitas jangka pendek (current assets to current liabilities), rasio jumlah liabilitas terhadap ekuitas (total liabilities to equity), dan rasio jumlah liabilitas terhadap jumlah aset (total liabilities to total assets). Di lain pihak, kinerja saham diukur dengan jumlah saham beredar (number of outstanding shares) dan laba bersih per saham (earnings per share). Selain itu, kami memperdalam temuan dengan melakukan analisis faktor untuk menguji validitas instrumen rasio keuangan.

\section{ANALISIS DAN PEMBAHASAN}

\subsection{Laporan Posisi Keuangan}

Jika dianalisis dari aspek aset perusahaan, maka terlihat bahwa terjadi peningkatan signifikan aset perusahaan selama dua belas tahun dari tahun 2004 hingga 2015, yakni dari Rp372 miliar pada tahun 2004 menjadi Rp9 triliun pada tahun 2015. Artinya, selama dua belas tahun operasi perusahaan terjadi kenaikan jumlah aset sebesar 2333 persen, atau rata-rata sekitar 194 persen per tahun. Meskipun demikian, pertumbuhan aset tidak lancar terlihat lebih stabil dibandingkan pertumbuhan aset lancar yang cenderung lebih fluktuatif. Kami menemukan ada dua kali pertumbuhan aset perusahaan secara dramatis. Pertumbuhan dramatis pertama berada dalam periode 2007/2006 di mana terjadi kenaikan pertumbuhan jumlah aset dari tahun 2006 ke 2007 sebesar 118 persen. Secara rinci, kenaikan pertumbuhan jumlah aset ini disebabkan oleh pertumbuhan aset tidak lancar yang naik drastis sebesar 169 persen. Pada saat sama, pertumbuhan aset lancar tidak terlalu besar yaitu sekitar 60 persen. Selanjutnya, pertumbuhan dramatis kedua berada dalam periode 2011/2010 di mana terjadi kenaikan pertumbuhan jumlah aset dari tahun 2010 ke 2011 sebesar 85 persen. Berbeda dengan yang pertama tadi, kenaikan pertumbuhan jumlah aset dalam periode ini lebih banyak disebabkan oleh pertumbuhan aset lancar yang naik drastis sebesar 159 persen. Pada saat sama, pertumbuhan aset lancar tidak terlalu besar yaitu sekitar 47 persen. Pertumbuhan aset lancar yang demikian besar pada periode 2011/2010 ini berdampak pada pertumbuhan aset lancar periode berikutnya (2012/2011) yang menurun menjadi negatif sebelas persen.

Jika dianalisis dari aspek liabilitas, maka terlihat bahwa terjadi peningkatan liabilitas perusahaan terutama sejak tahun 2010 hingga 2015, yakni dari Rp14,3 miliar pada tahun 2010 menjadi Rp5,1 triliun pada tahun 2015. Artinya, selama enam tahun terjadi kenaikan jumlah liabilitas relatif besar yaitu sebesar 35508 persen, atau rata-rata sekitar 5918 persen per tahun. Jika kita kaitkan dengan uraian sebelumnya tentang tren aset perusahaan, maka kenaikan liabilitas pada periode 2011/2010 ini juga bisa diamati/terlihat dari adanya pertumbuhan dramatis jumlah aset dalam periode 2011/2010 di mana terjadi kenaikan pertumbuhan jumlah aset dari tahun 2010 ke 2011 sebesar 85 persen. Pertumbuhan liabilitas jangka panjang terlihat lebih fluktuatif dibandingkan pertumbuhan liabilitas jangka pendek.

Kami juga menganalisis hubungan antara jumlah liabilitas dan ekuitas. Sumber pendanaan perusahaan mengalami peningkatan dari tahun 2004 hingga 2015, yang bisa berasal baik dari liabilitas maupun ekuitas. Dalam periode 2004 hingga 2010, pendanaan perusahaan sebagian besar berasal dari ekuitas. Namun, mulai tahun 2011, pendanaan perusahaan mengalami peningkatan signifikan yang berasal dari liabilitas maupun ekuitas. Setelah tahun 2012, terjadi tren di mana pendanaan yang berasal dari liabilitas lebih besar dibandingkan ekuitas. Hal ini mengindikasikan bahwa perusahaan terlihat semakin berani melakukan ekspansi bisnis dengan memanfaatkan sumber dana dari ekternal dalam bentuk liabilitas, baik yang bersifat jangka pendek maupun jangka panjang. 


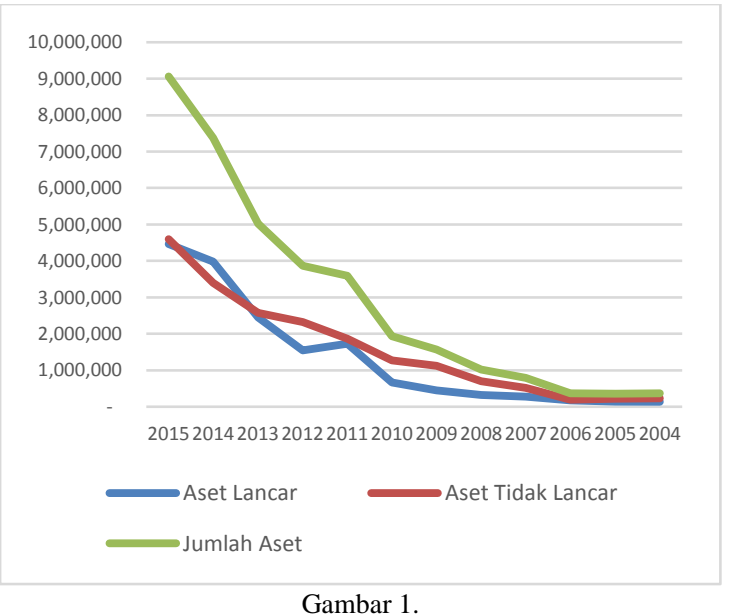

Tren Aset Lancar, Aset Tidak Lancar dan Jumlah Aset

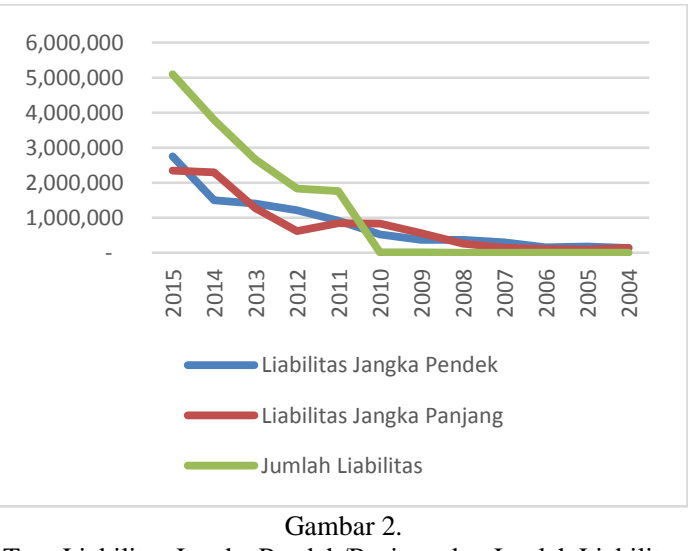

Tren Liabilitas Jangka Pendek/Panjang dan Jumlah Liabilitas

\subsection{Laporan Laba Rugi}

Beberapa indikator yang bisa digunakan untuk menganalisis laporan laba-rugi perusahaan adalah penjualan neto, beban pokok penjualan, laba bruto, beban usaha, dan laba usaha. Temuan menarik terlihat untuk penjualan neto dan beban pokok penjualan. Hasil analisis memperlihatkan bahwa awalnya penjualan neto dan beban pokok penjualan menunjukkan pertumbuhan lambat sejak tahun 2004 hingga 2010. Selama periode ini, rata-rata pertumbuhan penjualan neto hanya sekitar 22 persen. Namun, setelah tahun 2010, pertumbuhan penjualan neto dan beban pokok penjualan terlihat mengalami peningkatan relatif pesat. Penjualan neto pada tahun 2010 hanya sebesar Rp705 miliar, sedangkan pada tahun 2015 meningkat drastis menjadi Rp6 triliun. Artinya, selama lima tahun terjadi kenaikan jumlah penjualan neto sebesar 752 persen, atau rata-rata sekitar 150 persen per tahun. Jika dikaitkan dengan uraian sebelumnya, diduga kenaikan ini didorong pula oleh adanya tambahan kucuran pendanaan, baik melalui ekuitas maupun liabilitas (jangka pendek dan jangka panjang).

Meskipun penjualan neto meningkat pesat, beban pokok penjualan juga mengalami peningkatan relatif tinggi. Hal ini menyebabkan pertumbuhan laba bruto terlihat tidak terlalu signifikan. Perusahaan perlu melakukan berbagai inovasi dan efisiensi produksi, serta memanfaatkan kemajuan teknologi untuk menurunkan biaya produksi dari waktu ke waktu. Namun demikian, ada sedikit tren positif mengingat peningkatan penjualan neto lebih besar dibandingkan peningkatan beban pokok penjualan. Pertumbuhan signifikan penjualan neto dan beban pokok penjualan berada dalam periode 2011/2010 di mana terjadi kenaikan pertumbuhan penjualan neto dari tahun 2011 ke 2012 sebesar 149 persen. Pertumbuhan ini kemungkinan besar didorong oleh adanya suntikan dana dalam bentuk tambahan modal (ekuitas) dan pinjaman (liabilitas). Seperti dijelaskan sebelumnya, pada periode ini terlihat adanya pertumbuhan aset, terutama aset lancar sebesar 159 persen. Temuan menarik lain terjadi atas laporan laba rugi periode 2007/2006. Laba usaha terlihat mengalami pertumbuhan signifikan dari tahun 2006 ke 2007, yakni sebesar 197 persen. Pertumbuhan ini kemungkinan besar didorong oleh adanya suntikan modal (ekuitas) pada periode tersebut. Selain itu, kenaikan ini terlihat tinggi disebabkan oleh rendahnya laba usaha pada tahun sebelumnya.

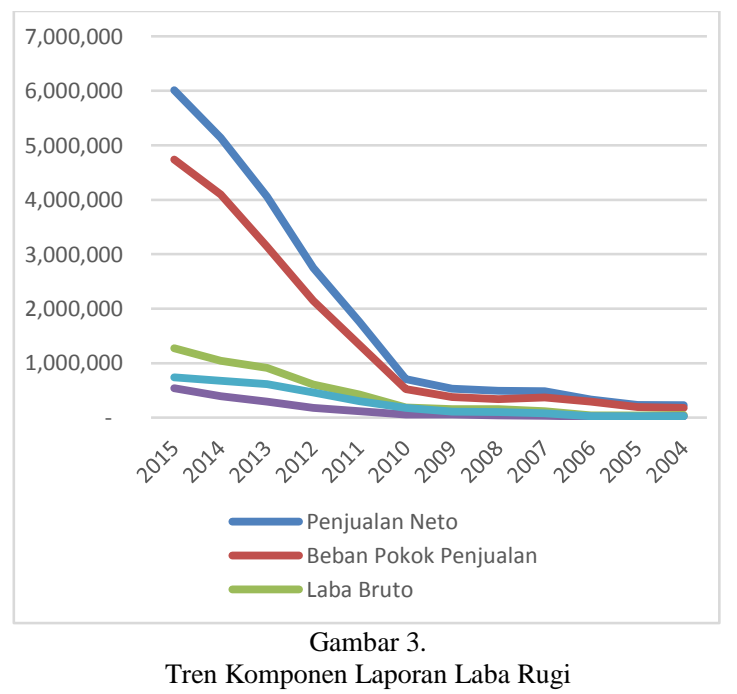

\subsection{Margin Laba Kotor, Margin Laba Usaha, dan} Margin Laba Bersih

Selama kurun waktu 12 tahun dari 2004 hingga 2015, marjin laba kotor (gross profit margin) perusahaan berada pada titik terendah pada tahun 2006. Namun setelah itu, kinerja bisnis perusahaan mengalami peningkatan sangat signifikan hingga klimaksnya terjadi pada tahun 2008. Hal ini terlihat dari adanya kenaikan marjin laba kotor dari tiga belas persen pada tahun 2006 menjadi 31,26 persen pada tahun 2008. Kenaikan marjin laba kotor yang sangat besar ini disebabkan oleh adanya suntikan modal (ekuitas) yang dipergunakan untuk membeli barang modal (aset tidak lancar) pada tahun 2006. Kebijakan ini terlihat sangat efektif mendongkrak marjin laba kotor perusahaan. Setelah tahun 2008, marjin laba kotor terus mengalami penurunan relatif tajam hingga tahun 2015. Sebenarnya pada tahun 2010, perusahaan memperoleh suntikan dana relatif besar yang berasal dari tambahan modal ekuitas dan pinjaman (jangka panjang dan pendek). Saat itu, perusahaan sebenarnya memperoleh tambahan aset lancar dengan jumlah relatif besar. Namun, jika kita cermati dari sisi marjin laba kotor, maka suntikan dana ini terlihat kurang bisa dimanfaatkan secara baik oleh perusahaan.

Tren marjin laba usaha (operating income margin) serupa dengan marjin laba kotor. Dalam grafik, kurva marjin laba usaha berada di bawah marjin laba 
kotor. Selama kurun waktu dua belas tahun dari 20042015, marjin laba usaha perusahaan berada pada titik terendah pada tahun 2006. Namun setelah itu, kinerja bisnis perusahaan mengalami peningkatan sangat signifikan hingga klimaksnya terjadi pada tahun 2008. Hal ini terlihat dari adanya kenaikan marjin laba usaha dari delapan persen pada tahun 2006 menjadi 22,21 persen pada tahun 2008. Kemungkinan besar kenaikan marjin laba usaha ini juga disebabkan oleh adanya suntikan modal (ekuitas) yang dipergunakan untuk membeli barang modal (aset tidak lancar) pada tahun 2006. Kebijakan ini terlihat sangat efektif mendongkrak marjin laba usaha perusahaan. Setelah tahun 2008, marjin laba usaha terus mengalami penurunan hingga tahun 2015. Pada tahun 2010, perusahaan sesungguhnya memperoleh suntikan dana relatif besar yang berasal dari tambahan modal ekuitas dan pinjaman (jangka panjang dan pendek). Saat itu, perusahaan sebenarnya memperoleh tambahan aset lancar dengan jumlah relatif besar. Namun, jika kita cermati dari sisi marjin laba usaha, maka suntikan dana ini terlihat kurang bisa dimanfaatkan secara baik oleh perusahaan.

Menurut Deran, Iskenderoglu, dan Erduru (2014), rasio marjin laba bersih (net profit margin) adalah laba bersih dibagi pendapatan. Rasio marjin laba bersih, rasio pengembalian atas aset (return on assets ratio), dan rasio pengembalian atas ekuitas (return on equity ratio) merupakan indikator untuk mengukur rasio profitabilitas. Sejak tahun 2004 hingga 2015, marjin laba bersih perusahaan pernah berada pada titik terendah pada tahun 2006. Namun setelah itu, marjin laba bersih mencapai titik tertinggi pada tahun 2010. Hal ini sedikit berbeda dengan marjin laba kotor dan marjin laba usaha yang mencapai titik tertinggi pada dua tahun sebelumnya, yaitu tahun 2008. Pada tahun 2006, angka marjin laba bersih sangat kecil yakni hanya sebesar 0,04 persen, sedangkan pada tahun 2010 marjin laba bersih mampu mencapai angka 10,76 persen. Kenaikan marjin laba bersih ini diduga disebabkan oleh adanya suntikan modal (ekuitas) yang dipergunakan untuk membeli barang modal (aset tidak lancar) pada tahun 2006. Kebijakan ini terlihat sangat efektif mendongkrak marjin laba bersih perusahaan meskipun hasilnya baru terasa beberapa waktu kemudian. Setelah tahun 2010, marjin laba bersih cenderung mengalami penurunan hingga tahun 2015. Sebenarnya pada tahun 2010, perusahaan memperoleh suntikan dana relatif besar yang berasal dari tambahan modal ekuitas dan pinjaman (jangka panjang dan pendek). Saat itu, perusahaan sebenarnya memperoleh tambahan aset lancar dengan jumlah relatif besar. Namun, jika kita cermati dari sisi marjin laba bersih, maka suntikan dana ini terlihat belum bisa dimanfaatkan dengan baik oleh perusahaan.

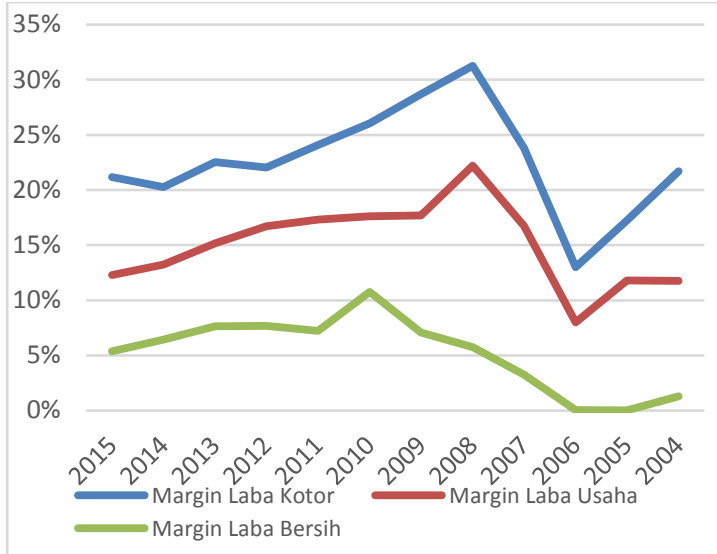

Gambar 4

Tren Margin Laba Kotor, Laba Usaha, dan Laba Bersih

\subsection{Rasio Operasional}

Seperti diuraikan sebelumnya, rasio operasional mencakup rasio laba usaha terhadap ekuitas, rasio laba bersih terhadap ekuitas, rasio laba usaha terhadap jumlah aset, dan rasio laba bersih terhadap jumlah aset. Rasio laba usaha terhadap ekuitas menunjukkan tren fluktuatif sejak tahun 2005 hingga 2015. Angka rasio berfluktuasi dalam rentang antara 1328 persen. Angka rasio menunjukkan nilai terendah pada tahun 2005 yakni sebesar tiga belas persen, sedangkan angka tertinggi terjadi pada tahun 2006 yaitu sebesar 28,7 persen. Rasio tertinggi yang diperoleh pada tahun 2006 sebenarnya bukan disebabkan oleh tingginya laba usaha, tetapi lebih disebabkan oleh masih rendahnya ekuitas. Ada suntikan modal dalam jumlah tidak terlalu besar, tetapi modal yang terbatas ini dimanfaatkan secara efektif oleh manajemen untuk menghasilkan laba. Pada tahun 2010 perusahaan juga memperoleh tambahan modal dan pinjaman, tetapi rasio laba usaha terhadap ekuitas justru jatuh pada tahun 2011 meskipun sempat naik pada tahun 2013. Namun, setelah tahun 2013 secara perlahan dan sedikit fluktuatif rasio ini semakin menurun hingga tahun 2015.

Selanjutnya, rasio laba bersih terhadap ekuitas cenderung menunjukkan tren meningkat sejak tahun 2005 hingga 2013. Angka rasio berfluktuasi dalam rentang antara 0,01-14,75 persen. Angka rasio menunjukkan nilai terendah pada tahun 2005 yakni sebesar 0,01 persen, sedangkan angka tertinggi terjadi pada tahun 2013 yaitu sebesar 14,75 persen. Rasio tertinggi yang diperoleh pada tahun 2013 disebabkan oleh naiknya laba bersih. Jika melihat angka rasio tertinggi ini, maka kita bisa mengatakan bahwa suntikan modal dan pinjaman (jangka pendek dan jangka panjang) yang relatif besar pada tahun 2010 terlihat mulai memberikan hasil signifikan bagi perusahaan - meskipun sempat turun dahulu pada tahun 2011. Artinya, modal dan pinjaman ini bisa dikelola dengan baik oleh manajemen untuk menghasilkan laba bersih dengan nilai signifikan. Namun demikian, setelah tahun 2011 secara perlahan dan sedikit fluktuatif rasio ini semakin menurun hingga tahun 2015.

Untuk rasio laba usaha terhadap jumlah aset, hasil menunjukkan adanya tren fluktuatif sejak tahun 2005 hingga 2015. Angka rasio berfluktuasi dalam rentang antara 6,01-12,24 persen. Angka rasio menunjukkan nilai terendah pada tahun 2009 yakni sebesar 6,01 persen, sedangkan angka tertinggi terjadi pada tahun 2013 yaitu sebesar 12,24 persen. Rasio 
tertinggi yang diperoleh pada tahun 2013 merupakan dampak lanjutan dari adanya suntikan modal dan pinjaman pada tahun 2010. Namun demikian, tren positif ini tidak bisa dipertahankan, sehingga rasio terus mengalami penurunan pada tahun 2014 dan 2015.

Jika mengamati tren rasio laba bersih terhadap jumlah aset, secara umum hasilnya mirip dengan tren rasio laba bersih terhadap ekuitas. Namun, tren rasio laba bersih terhadap jumlah aset terlihat lebih stabil dibanding tren rasio laba bersih terhadap ekuitas yang cenderung lebih fluktuatif. Tren rasio laba bersih terhadap jumlah aset menunjukkan tren meningkat sejak tahun 2006 hingga 2013. Angka rasio berfluktuasi dalam rentang antara 0,04-6,92 persen. Angka rasio menunjukkan nilai terendah pada tahun 2005 yakni sebesar 0,04 persen, sedangkan angka tertinggi terjadi pada tahun 2013 yaitu sebesar 6,92 persen. Rasio tertinggi yang diperoleh pada tahun 2013 disebabkan oleh naiknya laba bersih. Jika melihat angka rasio tertinggi ini, maka kita bisa mengatakan bahwa suntikan modal dan pinjaman (jangka pendek dan jangka panjang) yang relatif besar pada tahun 2010 terlihat mulai memberikan hasil signifikan bagi perusahaan - meskipun membutuhkan waktu tiga tahun. Artinya, modal dan pinjaman ini bisa dikelola dengan baik oleh manajemen untuk menghasilkan laba bersih dengan nilai signifikan. Namun, setelah tahun 2013 secara perlahan rasio ini semakin menurun hingga tahun 2015.

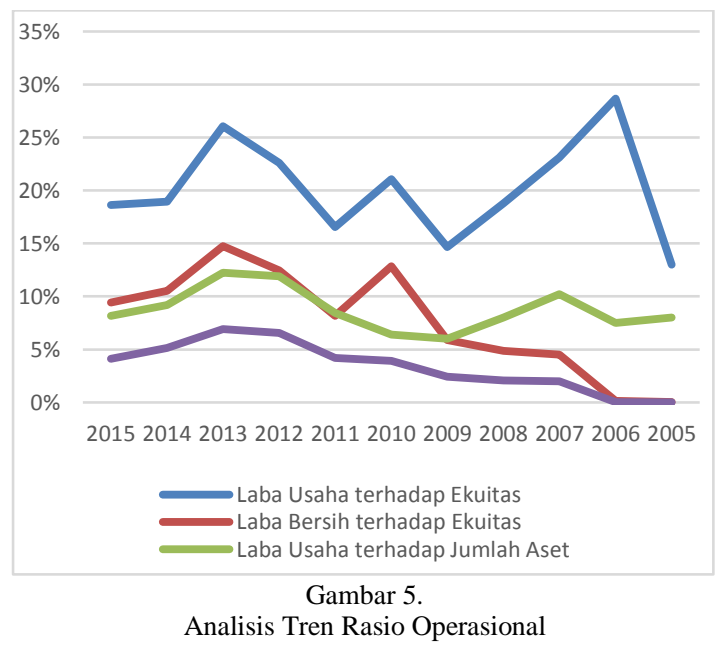

\subsection{Rasio Keuangan}

Rasio keuangan meliputi rasio aset lancar terhadap liabilitas jangka pendek, rasio jumlah liabilitas terhadap ekuitas, dan rasio jumlah liabilitas terhadap jumlah aset. Rasio aset lancar terhadap liabilitas jangka pendek menunjukkan tren meningkat dan fluktuatif sejak tahun 2005 hingga 2015. Angka rasio berfluktuasi dalam rentang antara 0,82-2,66. Angka rasio menunjukkan nilai terendah pada tahun 2005 yakni sebesar 0,82 , sedangkan angka tertinggi terjadi pada tahun 2014 yaitu sebesar 2,66 . Namun, rasio ini pernah turun agak tajam menjadi hanya 1,27 pada tahun 2012. Saat itu perusahaan menghadapi masalah keuangan karena aset lancar yang dimiiki tidak cukup memadai untuk bisa menutupi utang jangka pendek. Namun, selanjutnya perusahaan mampu melakukan pembenahan, sehingga rasio aset lancar terhadap liabilitas jangka pendek semakin membaik hingga tahun 2014. Ironisnya, setahun kemudian (tahun 2015) rasio ini kembali mengalami penurunan tajam.
Di lain pihak, rasio jumlah liabilitas terhadap ekuitas cenderung menunjukkan tren menurun dan fluktuatif sejak tahun 2005 hingga 2015. Angka rasio berfluktuasi dalam rentang antara 0,9-2,28. Angka rasio menunjukkan nilai terendah pada tahun 2012 yakni sebesar 0,9, sedangkan angka tertinggi terjadi pada tahun 2010 yaitu sebesar 2,28. Kondisi keuangan perusahaan pada tahun 2010 sangat mengkhawatirkan karena besarnya jumlah utang. Tingginya rasio ini disebabkan perusahaan memperoleh pinjaman jangka panjang dan jangka pendek dengan jumlah lebih besar. Namun, rasio ini langsung menurun tajam pada tahun 2011. Selanjutnya tantangan pimpinan perusahaan adalah menjaga agar rasio jumlah liabilitas terhadap ekuitas berada di kisaran angka satu atau lebih rendah lagi.

Berikutnya, rasio jumlah liabilitas terhadap jumlah aset menunjukkan tren menurun tipis sejak tahun 2005 hingga 2011, lalu cenderung stabil di angka 0,5 sejak tahun 2011 hingga 2015. Rasio sebesar 0,5 berarti bahwa jumlah utang perusahaan sebesar separuh jumlah aset perusahaan. Semakin kecil rasio ini memperlihatkan semakin sehat kondisi keuangan perusahaan. Selanjutnya, tantangan pimpinan perusahaan adalah menjaga agar rasio jumlah liabilitas terhadap jumlah aset berada di kisaran angka 0,5 atau lebih rendah lagi. Selengkapnya, tren rasio keuangan perusahaan bisa dilihat pada grafik.

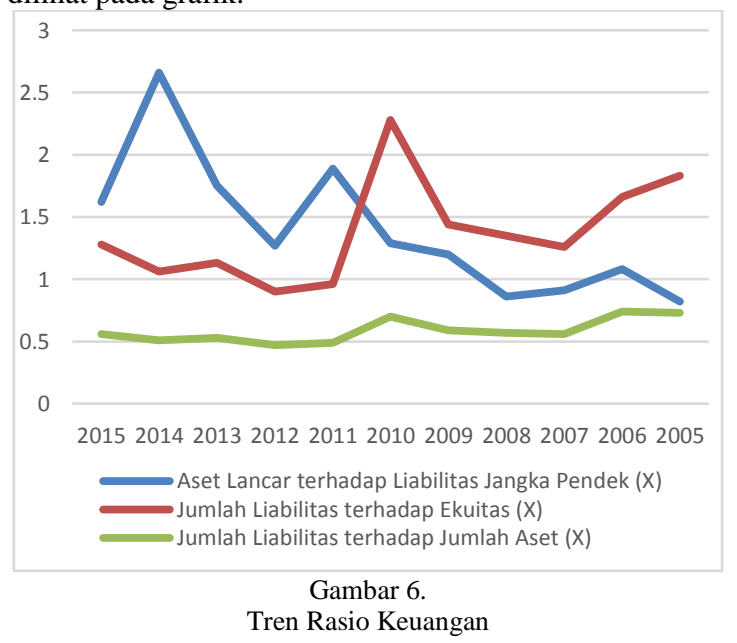

\subsection{Analisis Kinerja Saham}

Kinerja saham diukur dengan jumlah saham beredar dan laba bersih per saham. Jumlah saham beredar mengalami peningkatan sejak tahun 2005 hingga 2015. Kenaikan jumlah saham terlihat pada tahun 2008, 2011, dan 2014. Hal ini menyebabkan peningkatan ekuitas perusahaan. Sejak 2005 hingga 2015, laba bersih per saham selalu mengalami peningkatan. Namun demikian, jika kita telaah dari sisi pertumbuhan dibanding tahun sebelumnya, maka terlihat bahwa pertumbuhan laba bersih per saham pada tahun 2015 mengalami penurunan dibanding tahun 2014, yakni sebesar 9,1 persen. Pertumbuhan negatif juga pernah terjadi pada tahun 2012 dibandingkan tahun 2011 yang turun sebesar 2,7 persen. Lainnya, laba bersih per saham selalu mengalami pertumbuhan positif. Selengkapnya, tren laba bersih per saham dari tahun 2005 hingga 2015 dan pertumbuhannya bisa dilihat dalam grafik di bawah ini. 

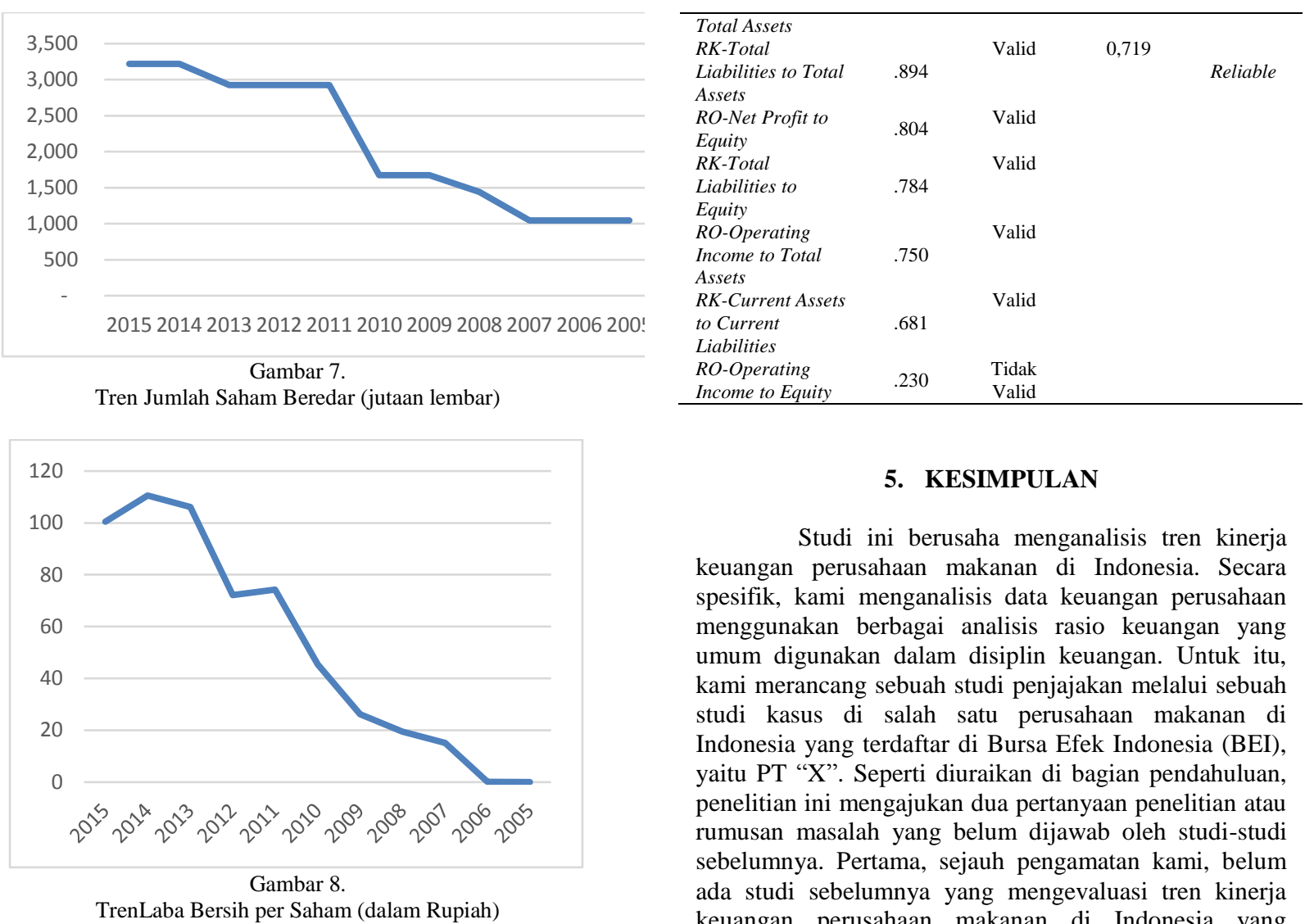

Selanjutnya, kami melakukan uji validitas atas indikator rasio keuangan (RK) dan rasio operasional (RO) menggunakan teknik analisis faktor. Seluruh indikator untuk rasio keuangan dianggap valid karena memiliki skor muatan faktor lebih besar dari 0,6. Di lain pihak, seluruh indikator untuk rasio operasional dianggap valid karena memiliki skor muatan faktor lebih besar dari 0,6 , kecuali satu indikator yaitu operating income to equity. Sebagai salah satu indikator rasio operasional, studi ini menemukan bahwa nilai muatan indikator operating income to equity tidak valid karena memiliki nilai muatan faktor sebesar 0,230 (lebih kecil dari 0,6). Oleh karena itu, rasio pendapatan usaha terhadap ekuitas sebenarnya tidak tepat digunakan sebagai alat ukur rasio keuangan selama ini, sehingga disarankan untuk tidak digunakan untuk menganalisis rasio keuangan, khususnya rasio operasional. Sebaliknya, rasio net profit to total assets memiliki nilai muatan faktor terbesar yaitu 0,935 . Artinya, indikator ini sesungguhnya merupakan alat ukur paling tepat yang bisa dianggap paling mewakili analisis rasio keuangan secara keseluruhan, lalu diikuti oleh indikator lain yang memiliki skor muatan faktor lebih rendah. Selain uji validitas, kami juga melakukan uji reliabilitas. Hasilnya, instrumen penelitian ini dinilai bisa dipercaya (reliable) karena memiliki skor Cronbach's Alpha lebih dari 0,6, tepatnya 0,719 . Selengkapnya, hasil uji validitas dan reliabilitas bisa dilihat dalam tabel di bawah ini.

Tabel 3. Uji Validitas dan Reliabilitas Rasio Keuangan

\begin{tabular}{ccccc}
\hline $\begin{array}{c}\text { Indikator } \\
\text { Rasio Keuangan }\end{array}$ & \multicolumn{2}{c}{ Uji Validitas } & \multicolumn{2}{c}{ Uji Reliabilitas } \\
\cline { 2 - 5 } & $\begin{array}{c}\text { Factor } \\
\text { Loadi } \\
\text { ng }\end{array}$ & $\begin{array}{c}\text { Kesimpul } \\
\text { an }\end{array}$ & $\begin{array}{c}\text { Cronbac } \\
\text { h's Alpha }\end{array}$ & $\begin{array}{c}\text { Kesimpul } \\
\text { an }\end{array}$ \\
\hline RO-Net Profit to & .935 & Valid & & \\
\hline
\end{tabular}

\section{KESIMPULAN}

Studi ini berusaha menganalisis tren kinerja keuangan perusahaan makanan di Indonesia. Secara spesifik, kami menganalisis data keuangan perusahaan menggunakan berbagai analisis rasio keuangan yang umum digunakan dalam disiplin keuangan. Untuk itu, kami merancang sebuah studi penjajakan melalui sebuah studi kasus di salah satu perusahaan makanan di Indonesia yang terdaftar di Bursa Efek Indonesia (BEI), yaitu PT "X". Seperti diuraikan di bagian pendahuluan, penelitian ini mengajukan dua pertanyaan penelitian atau rumusan masalah yang belum dijawab oleh studi-studi sebelumnya. Pertama, sejauh pengamatan kami, belum ada studi sebelumnya yang mengevaluasi tren kinerja keuangan perusahaan makanan di Indonesia yang terdaftar di Bursa Efek Indonesia (BEI) secara komprehensif, yang berbasis pada rasio operasional, rasio keuangan, dan kinerja saham secara simultan. Kedua, sejauh pengamatan kami, belum ada studi sebelumnya yang melakukan pengujian validitas dan reliabilitas terhadap setiap alat ukur dari rasio keuangan yang banyak dipahami dan digunakan selama ini.

Secara umum, kami menemukan bahwa kinerja keuangan perusahaan cenderung berfluktuasi dari waktu ke waktu. Jika diamati dari sisi penjualan, maka kinerja perusahaan terlihat sangat positif karena menunjukkan peningkatan sejak tahun 2010. Namun, jika kita amati dari marjin laba, maka kinerja keuangan perusahaan cenderung mengalami penurunan. Tren rasio operasional menunjukkan penurunan sejak tahun 2013 hingga 2015. Lalu, hasil analisis menggunakan teknik analisis faktor memperlihatkan bahwa rasio laba bersih terhadap total aset merupakan indikator terkuat yang paling mewakili analisis rasio keuangan perusahaan. Berbeda dengan studi-studi sebelumnya, penelitian ini menemukan bahwa rasio laba usaha terhadap ekuitas terbukti bukanlah alat ukur yang valid untuk rasio keuangan.

Penelitian ini berhasil memperoleh temuan menarik dan berbeda dari temuan studi-studi sebelumnya. Penelitian ini telah membuktikan bahwa rasio laba usaha terhadap ekuitas terbukti tidak valid sebagai alat ukur rasio keuangan. Seperti diketahui, studi dan pemahaman selama ini menganggap rasio laba usaha terhadap ekuitas (operating income to equity) sebagai salah satu alat ukur rasio operasional. Namun demikian, beberapa alat ukur lain, seperti laba bersih terhadap aset keseluruhan (net profit to total assets), laba bersih terhadap ekuitas (net profit to equity), dan pendapatan usaha terhadap aset keselutuhan (operating income to total assets) tetap terbukti valid dan reliable sebagai alat ukur rasio operasional, seperti temuan studi-studi 
sebelumnya. Secara ringkas, penelitian ini berhasil memberikan kontribusi signifikan dan kebaruan bagi kepentingan praktis maupun teoritis (pengetahuan) melalui temuan kami yakni berhasil memvalidasi alat ukur atau komponen rasio keuangan yang telah dipahami dan digunakan selama ini.

\section{DAFTAR PUSTAKA}

Ahrendsen, B.L. \& Katchova, A.L. 2012. Financial ratio analysis using ARMS data. Agricultural Finance Review, 72(2), 262-272.

Al-Tamimi, H.A.H. \& Lootah, A.M. 2007. Evaluating the operational and profi tability effi ciency of a UAE-based commercial bank. Journal of Financial Services Marketing, 11(4). 333-348.

Aripin, N., Tower, G. \& Taylor, G. 2011. Insights on the diversity of financial ratios communication. Asian Review of Accounting, 19(1), 68-85.

Courtis, J.K. 1996. Annual report financial ratio component consistency. Asian Review of Accounting, 4(1), 146-162.

Deran, A., Iskenderoglu, O. \& Erduru, I. 2014. Regional Differences and Financial Ratios: A Comparative Approach on Companies of ISE City Indexes. International Journal of Economics and Financial Issues, 4(4), 946955.

Gallizo, J.L., Gargallo, P. \& Salvador, M. 2008. Multivariate Partial Adjustment of Financial Ratios: A Bayesian Hierarchical Approach. Journal of Applied Econometrics, 23(1), 43-64.

Gibson, C. 1982. Financial ratios in annual reports. The CPA Journal, 52(9), 18-29.

Graham, J.R., Harvey, C.R. \& Rajgopal, S. 2005. The economic implications of corporate financial reporting. Journal of Accounting and Economics, 40(1), 3-73.

Healy, P.M. \& Palepu, K.G. 2001. Information asymmetry, corporate disclosure, and the capital markets: a review of the empirical disclosure literature. Journal of Accounting and Economics, 31(1-3) 405-40.

Horrigan, J.O. 1965. Some Empirical Bases of Financial Ratio Analysis. The Accounting Review, 40(3), 558-568.
Hsu, H.C. 2010. Using MSN Money To Perform Financial Ratio Analysis. Journal of College Teaching and Learning, 17(9), 25-35.

Kuo, C. 2014. Effect of Enterprise Resource Planning Information System on Business Performance: An Empirical Case of Taiwan. Journal of Applied Finance \& Banking, 4(2), 1-19.

McMahon, R.G.P. 1999. Modelling the Extent of Financial Reporting Practices Amongst Australian Manufacturing SMEs. Small Business Economics, 13(2), 81-96.

Neophytou, E. \& Molinero, C.M. 2004. Predicting corporate failure in the UK a multidimensional scaling approach. Journal of Business Finance and Accounting, 31(5/6), 677-710.

Ong, S-W., Yap, V.C. \& Khong, R.W.L. 2011. Corporate failure prediction: a study of public listed companies in Malaysia. Managerial Finance, 37(6), $553-564$

Ozcan, Y.A. \& McCue, M.J. 1996. Development of a Financial Performance Index for Hospitals: DEA Approach. The Journal of the Operational Research Society, 47(1), 18-26.

Suarez, V., Lesneski, C. \& Denison, D. 2011. Making the Case for Using Financial Indicators in Local Public Health Agencies. American Journal of Public Health, 101(3), 419-425.

Subramanyam, K.R. \& Wild, J.J. 2009. Financial Statement Analysis. 10th ed., McGraw Hill, Boston, MA.

Sueyoshi, T. (2005). Financial Ratio Analysis of the Electric Power Industry. Asia - Pacific Journal of Operational Research, 22(3), 349-376.

Voulgaris, F., Doumpos, M. \& Zopounidis, C. 2000. On the Evaluation of Greek Industrial SMEs' Performance via Multicriteria Analysis of Financial Ratios. Small Business Economics, 15(2), 127-136.

Watson, A., Shrives, P. \& Marston, C. 2002. Voluntary disclosure of accounting ratios in the UK. British Accounting Review, 34(4), 289-313.

Yeh, Q-J. 1996. The Application of Data Envelopment Analysis in Conjunction with Financial Ratios for Bank Performance Evaluation. The Journal of the Operational Research Society, 47(8), 980-988. 